\title{
SISTEM MONITOR SINYAL PARTIAL DISCHARGE (PD) ONLINE BERBASIS TEKNOLOGI FIELD PROGRAMMABLE GATE ARRAY (FPGA) UNTUK KABEL LISTRIK TEGANGAN TINGGI MENGGUNAKAN PEMBANGKIT PULSA PICO SEBAGAI PD SIMULATOR
}

\author{
EMILLIANO $^{1}{ }^{*}$, CHANDAN KUMAR CHAKRABARTY $^{2}$, AHMAD BASRI $^{3}$, AGILESWARI $^{2}$ \\ K. RAMASAMY2 \\ ${ }^{1}$ Departemen Teknik Elektro, FMIPA, Universitas Padjadjaran \\ Jl. Raya Bandung-Sumedang Km.21 Jatinangor 45363, \\ Sumedang, Jawa Barat, Telp. 022-7796014
}

${ }^{2}$ Department of Electronic and Communication Engineering, College of Engineering (COE), Universiti Tenaga Nasional, Selangor, Malaysia

${ }^{3}$ Tenaga Nasional Berhad, Malaysia

Laboratory High Voltage Diagnostics System, Putrajaya, Malaysia

*email : emilliano@unpad.ac.id

\begin{abstract}
Abstrak. Kontribusi dari makalah ini adalah merancang Sistem Deteksi Online Partial Discharce (PD) dengan menggunakan sistem akuisisi data kecepatan tinggi dan teknologi FPGA (Field Programmable Gate Array) yang dapat menghitung jumlah sinyal PD tiap detik dengan simulasi sinyal PD pada Laboratorium dengan menggunakan Pembangkit Pulsa Pico. Prototype ini menggunakan FPGA Xilinx ML405 board dan ADC pada Microcontroller PIC 16F877A yang memiliki resolusi 8 bit, resolusi pengambilan sampel 2MS/s. Hasil akhir dari data adalah kesimpulan tingkat keparahan kualitas kabel XLPE (Cross Linked Polyethylene Insulation) bawah tanah tegangan tinggi berdasarkan jumlah sinyal PD yang terdeteksi tiap detik. Sistem ini telah dikembangkan dan berhasil diuji di Laboratorium menggunakan simulasi sinyal PD dengan Pembangkit Pulsa Pico. Sistem ini memungkinkan pengukuran dan perhitungan langsung sinyal PD dapat dilakukan tanpa menggunakan Komputer ataupun Oscilloscope. Permasalahan dalam penelitian ini adalah metode konvensional sistem deteksi Online Partial Discharge tidak dapat mendeteksi sinyal Partial Discharge lebih dari $5 \mathrm{Km}$ dari gardu induk. Penelitian ini mengembangkan metode deteksi Online Partial Discharge yang tidak konvensional yaitu menggunakan magnetic probe sensor dari atas tanah dan akuisisi data kecepatan tinggi dengan Teknologi FPGA sehingga sinyal PD pada kabel bawah tanah Tegangan Tinggi (kabel XLPE) dapat dideteksi dari atas tanah dengan jarak tak terbatas. Dalam pelaksanaan tes di laboratorium untuk rangkaian deteksi, ditunjukkan bahwa alat ini dapat mendeteksi sejumlah impuls dari Simulator Partial Discharge yang menggunakan Pembangkit Pulsa Pico dengan cukup akurat. Konsep ini akan digunakan di masa depan untuk mendeteksi sinyal Partial Discharge yang sesungguhnya yang dihasilkan oleh kabel bawah tanah berdaya tinggi di lapangan.
\end{abstract}

Kata kunci: Deteksi Partial Discharge, Teknologi FPGA, Kabel XLPE, Pembangkit Pulsa Pico, Sistem Monitor Sinyal PD, PIC Mikrokontroller

\begin{abstract}
The contribution of this paper is to design an Online Partial Discharce (PD) Detection System using a high speed data acquisition system and FPGA (Field Programmable Gate Array) technology that can calculate the number of PD signals per second by simulating PD signals in the Laboratory using Pico Pulse Generators. This prototype uses the Xilinx ML405 FPGA board and ADC on the PIC 16F877A microcontroller which has a resolution of 8 bits, a sampling resolution of $2 \mathrm{MS} / \mathrm{s}$. The
\end{abstract}

JIIF (Jurnal Ilmu dan Inovasi Fisika), ISSN: 2549-0516 
final result of the data is the conclusion of the severity of the high voltage underground XLPE (Cross Linked Polyethylene Insulation) cable based on the number of PD signals detected every second. This system has been developed and successfully tested in the Laboratory using a simulation of PD signals with Pico Pulse Generators. This system allows direct measurement and calculation of PD signals to be carried out without using a computer or Oscilloscope. The problem in this study is that the conventional method of detecting Online Partial Discharge systems cannot detect Partial Discharge signals more than $5 \mathrm{Km}$ from the substation. This research develops an unconventional Online Partial Discharge detection method that uses a magnetic probe sensor from the ground and high speed data acquisition with FPGA technology so that the PD signal on the High Voltage underground cable (XLPE cable) can be detected from above the ground with unlimited distance. In carrying out tests in the laboratory for the detection circuit, it was shown that this tool can detect a number of impulses from the Partial Discharge Simulator that uses the Pico Pulse Generator quite accurately. This concept will be used in the future to detect the true Partial Discharge signal generated by High-power underground cables in the field.

Keywords: Online Partial Discharge Detection, FPGA Technology, XLPE Cable, Pico Pulse Generator, PD signal Monitoring System, PIC Microcontroller

\section{Pendahuluan}

Sistem sirkuit pendeteksian partial discharge (PD) adalah sistem otomatis yang dapat mendeteksi dan menampilkan sinyal sementara agar mudah dibaca. Sistem deteksi ini dapat bekerja tanpa osiloskop, komputer atau peralatan pengukur lain yang mahal. Sinyal terdeteksi dengan menggunakan pendeteksi puncak.

Sistem deteksi Partial Discharge dapat membedakan antara sinyal pulsa sementara / pulsa transien dari sinyal derau / sinyal noise karena rangkaian deteksi Partial Discharge menggunakan nilai ambang detektor puncak / nilai Peak Detector Threshold. Jika amplitudo sinyal lebih dari nilai ambang batas / nilai Threshold dapat mendeteksi sinyal dan jika sinyal kurang dari nilai ambang batas / nilai Threshold itu tidak dapat mendeteksi sinyal.

Sistem ini memungkinkan pengukuran dan penghitungan langsung sinyal transien pada lebar pulsa 50-100 ns pada frekuensi sampling $20 \mathrm{MHz}$ dari generator pulsa Pico sebagai simulator sinyal Pelepasan Sebagian / sinyal Partial Discharge di lokasi. Semua hasil ditunjukkan untuk membuktikan konsep untuk mendeteksi Partial Discharge dengan lebar pulsa 5 ns di kabel bawah tanah daya tinggi. Sistem deteksi Partial Discharge dapat mendeteksi sinyal Partial Discharge secara akurat. Ini ditunjukkan dalam sistem detektor PD di mana LCD membaca 84.746 impuls per detik ketika ditetapkan pada $84.746 \mathrm{KHz}$ berulang menggunakan Pico pulse generator. Hasilnya menunjukkan bahwa detektor puncak output dapat mendeteksi sinyal puncak dari sinyal input ADC ketika lebar pulsa sinyal PD lebih dari $30 \mathrm{~ns}$ menggunakan ADC PIC Microcontroller 16F877A.

Permasalahan dalam penelitian ini adalah metode konvensional Sistem Deteksi Partial Discharge Online tidak dapat mendeteksi sinyal PD lebih dari $5 \mathrm{Km}$ dari gardu induk. Ini dapat mendeteksi sinyal Partial Discharge dalam kisaran antara 3 hingga $5 \mathrm{Km}$. Ada blind spot setelah $5 \mathrm{~km}$. Metode konvensional nyata dari sistem deteksi Partial Discharge online dapat mendeteksi sinyal Partial Discharge kabel bawah tanah tegangan tinggi dengan menjepit pemutusan kabel pentanahan dari gardu induk ke gardu induk lain atau terminal lain. Penelitian ini mengembangkan sistem pendeteksian Partial Discharge online baru yang tidak conventional dengan metode baru menggunakan sensor probe magnetik di permukaan tanah. Dengan menggunakan metode ini, sinyal Partial Discharge dapat dideteksi jarak tidak 
terbatas. Makalah ini adalah bagian dari pengembangan penelitian sistem deteksi Partial Discharge online yang tidak konvensional. Makalah ini berkontribusi dalam desain, sintesis dan menerapkan sistem deteksi Partial Discharge yang menggabungkan kedua teknologi FPGA dan ADC dari Mikrokontroler PIC.

Makalah ini melaporkan simulasi tingkat laboratorium di mana sinyal PD yang disimulasikan dihasilkan oleh generator impuls. Sinyal ini dimasukkan ke dalam mikrokontroler PIC berbiaya rendah untuk didigitalkan dan kemudian dihitung menggunakan FPGA dan ditampilkan sebagai jumlah dalam pembacaan LCD.

Partial Discharge (PD) didefinisikan oleh IEC 60270 [1] sebagai pelepasan listrik lokal yang hanya sebagian menjembatani isolasi antara konduktor dan yang mungkin atau mungkin tidak berdekatan dengan konduktor. Dalam kabel distribusi daya berisolasi XLPE, PD biasanya terjadi pada sambungan dan pengakhiran kabel. Ini adalah fenomena umum yang tidak menyebabkan kerusakan seketika pada isolasi kabel tetapi menghasilkan kerusakan isolasi dan akhirnya kerusakan. Oleh karena itu deteksi, pengukuran, dan klasifikasi PD telah menjadi alat penting untuk penilaian isolasi kabel untuk memastikan keandalan dan stabilitas kabel. Ketika pelepasan terdeteksi, kepentingan praktis untuk identifikasi termasuk sumber pelepasan, bentuknya, lokasi dan pola nadi. Ada tiga bagian utama dalam klasifikasi PD. Bagian pertama adalah deteksi PD; bagian kedua adalah ekstraksi fitur dari data PD mentah dan bagian ketiga adalah klasifikasi PD.

PD memancarkan energi akustik, optik, listrik, dan elektromagnetik [2]. Jadi, untuk deteksi PD, ada berbagai metode untuk mengumpulkan sinyal PD seperti sensor akustik [3], dengan pengembangan platform komputasi yang kuat dan bandwidth yang lebar, teknik pengukuran laju pengambilan sampel yang tinggi, analisis pulsa PD bergerak maju untuk membentuk, spektrum frekuensi dan analisis wavelet [4].

Metode umum untuk mendeteksi, mengukur, dan menemukan partial discharge di dalam kabel daya didasarkan pada metode deteksi lurus [5]. Untuk menemukan area partial discharge di sepanjang kabel, metode yang didasarkan pada gelombang elektromagnetik yang bergerak digunakan. Perambatan gelombang elektromagnetik karena partial discharge dipengaruhi oleh struktur kabel dan material. Penelitian tentang propagasi gelombang elektromagnetik karena Partial Discharge sangat terbatas. Bekerja oleh Weeks [6], Stone and Boggs [7], dan R. Jobava et al. [8] adalah beberapa contoh literatur yang ditemukan di daerah ini. Metode klasik untuk menganalisis perambatan gelombang elektromagnetik pada kabel daya adalah dengan menggunakan metode saluran transmisi (TLM). Namun, ketika struktur perangkat kompleks atau ketika mencoba menghitung bidang di luar struktur, analisis menggunakan pendekatan teori sirkuit menjadi sulit atau tidak mungkin. Baru-baru ini, teknik baru telah dikembangkan untuk analisis medan elektromagnetik transien numerik, yang menggunakan pemecah Maxwell untuk memecahkan masalah pada propagasi sinyal Partial Discharge $[9,10]$.

Untuk mengurangi masalah yang terkait dengan pengukuran PD di lapangan, sistem deteksi PD baru menggunakan sensor probe magnetik telah dibuat, dirancang, dianalisis, dan diuji untuk mendeteksi sinyal PD dalam simulasi lab dan di lapangan. Probe magnetik dapat mengambil medan magnet karena PD, pada $1 \mathrm{~m}$ di luar struktur kabel. 


\section{Metode Penelitian}

Teknologi FPGA menyimpan data mentah yang diperoleh Analog to Digital Converter (ADC) di blok detektor puncaknya. Data ini kemudian dikirim dan dianalisis oleh Teknologi FPGA. Adapun hasil dari Filter pada blok detektor puncak sinyal PD yang sudah dianalisis dan dihitung dalam 1 detik oleh Teknologi FPGA kemudian ditampilkan pada LCD text dan LCD graph pada Teknologi FPGA. Dari pembacaan jumlah sinyal PD, maka dapat disimpulkan bahwa sinyal PD dalam suatu lokasi kabel bawah tanah tegangan tinggi itu mempunyai Severity High, Medium atau Low berdasarkan dari banyaknya jumlah sinyal PD yang terdeteksi. Banyaknya sinyal PD yang terdeteksi menunjukkan pula tingkat keparahan kerusakan kualitas dari kabel tegangan tinggi bawah tanah tersebut (HV XLPE Cable). Gambar 1 menunjukkan diagram blok sistem deteksi pulsa menggunakan mikrokontroler PIC dan Teknologi FPGA. Pengambilan sampel dilakukan oleh ADC (Analog to Digital Converter) mikrokontroler PIC 16F877A dan penghitungan dilakukan oleh papan FPGA (ML405). Gambar 1 dan 4 menunjukkan koneksi antara Teknologi FPGA Xilinx ML405 yang dipasang dengan slot ModulEkspres LCD 16X2 Karakter pada port I/O 7 bit Teknologi FPGA dengan Mikrokontroller PIC 16F877A. Teknologi FPGA menggunakan Xilinx ML405 dan ADC dalam Mikrokontroler PIC 16F877A dihubungkan oleh kabel data logika 8 bit melalui pin FPGA, seperti yang ditunjukkan pada Gambar 2.
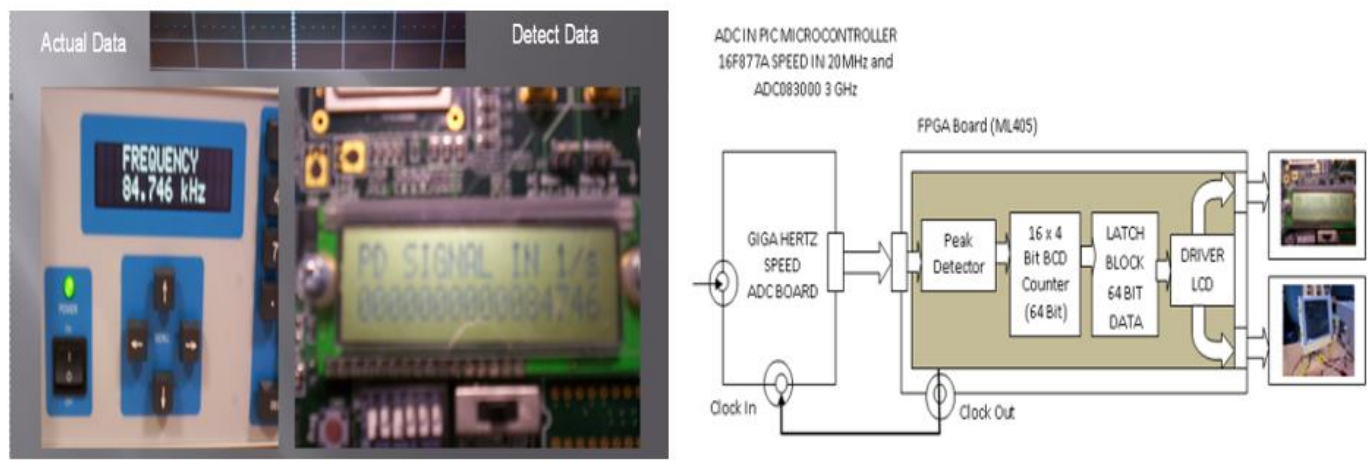

Gambar 1. Actual Data dan Detect Data Hasil Test Deteksi Impulse dan Blok Diagram

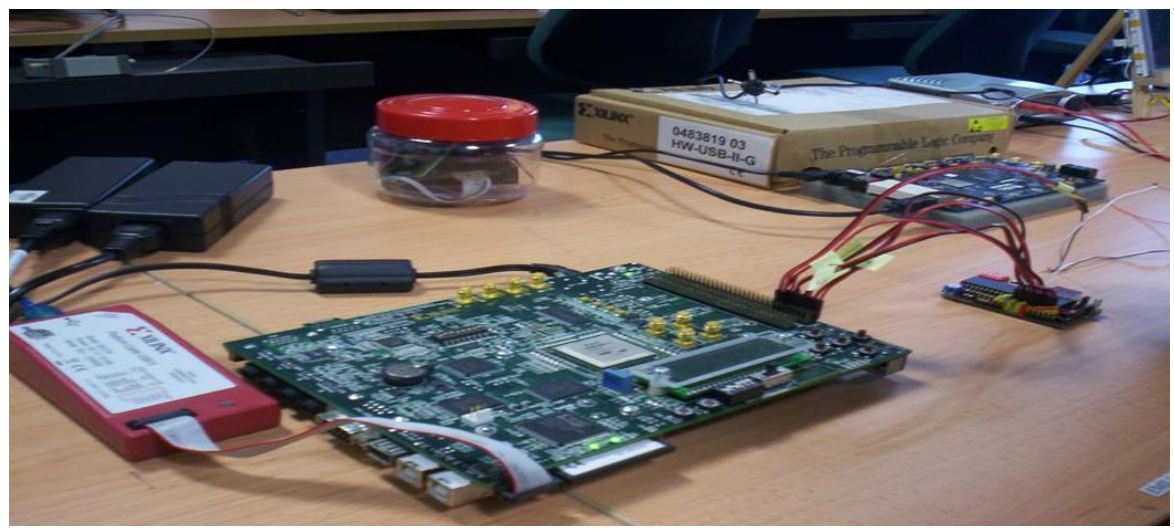

Gambar 2. Gambar Real Alat Pendeteksi Sinyal Partial Discharge dengan Teknologi FPGA dan Mikrokontroller PIC 16F877A 
Block Programming dalam Teknologi FPGA terdiri atas 5 blok program:

a. Blok ADC dan Detektor Puncak Pada Teknologi FPGA

b. Blok BCD counter dan blok reset Pada Teknologi FPGA

c. Blok Latch dalam implementasi Pada Teknologi FPGA

d. Blok Reset otomatis dalam implementasi Pada Teknologi FPGA

e. Blok LCD driver dalam implementasi Pada Teknologi FPGA

\subsection{Generator Pulsa Pico}

Gambar 3 menunjukkan generator impuls untuk mensimulasikan sinyal PD ketika melakukan pengujian sistem rangkaian deteksi PD dalam simulasi Lab. Generator pulsa Pico dapat menghasilkan pulsa sinyal PD dalam Pico detik hingga $100 \mathrm{~ns}$ dan generator pulsa Pico dapat menghasilkan amplitudo pulsa sebagai simulator sinyal PD dari 4,5 mV hingga $50000 \mathrm{mV}$ (maksimum 50 Volt) dengan pengulangan frekuensi dari $10 \mathrm{KHz}$ hingga $100 \mathrm{KHz}$.

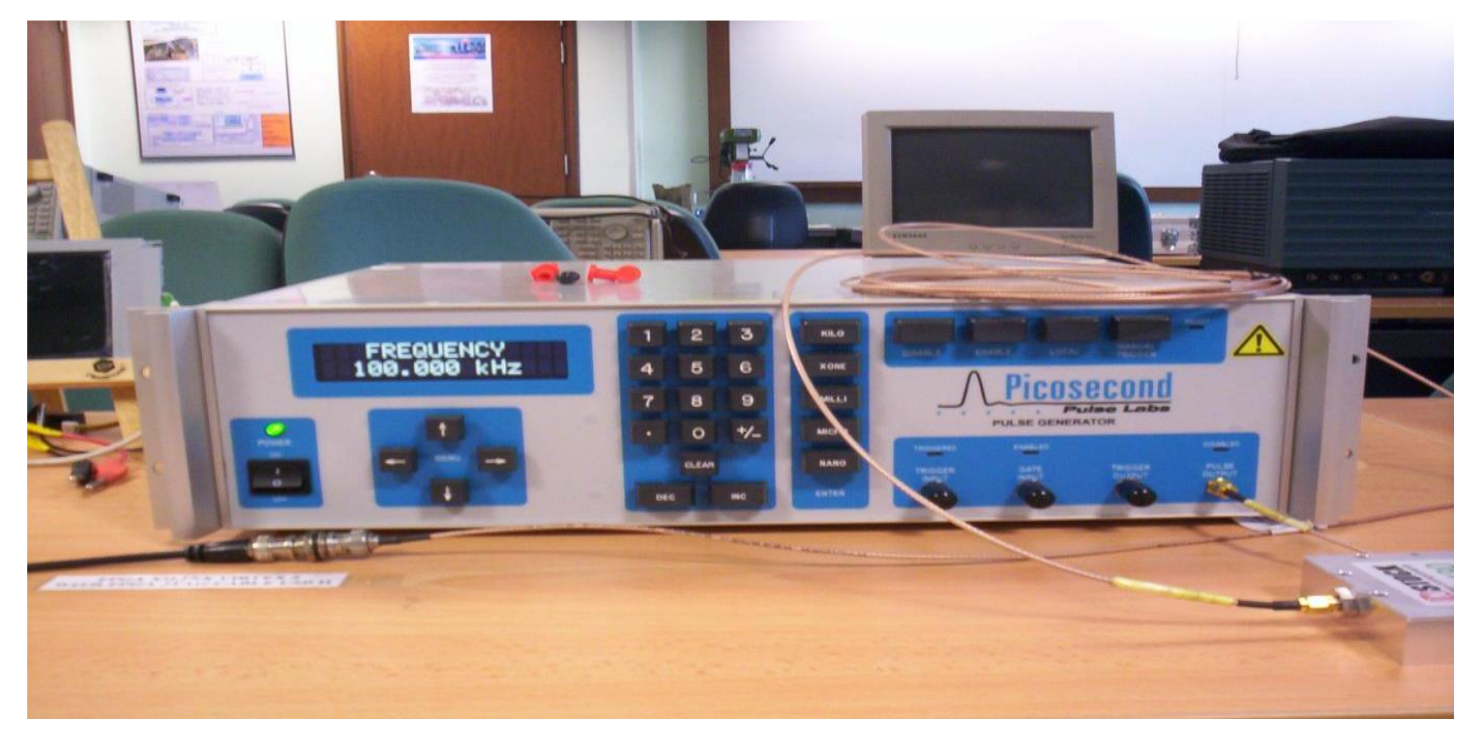

Gambar 3. Generator Pulsa Pico pada Sistem Deteksi PD

\subsection{Diagram Flowchart}

Input data dari ADC di seleksi oleh Blok Peak Detector System dengan metode threshold, setiap data yang berada diatas nilai threshold bernilai logic 1 dan Block BCD counter 64 bit data akan menghitung sebagai sebuah sinyal PD dan bertambah satu. Total nilai hasil hitungan Block BCD counter 64 bit akan ditahan oleh Block Latch 64 bit sehingga saat data BCD counter direset setiap 1 detik, maka data tampilan pada LCD tidak kembali ke nol melainkan bertahan di nilai terakhir. Sehingga kita bisa melihat nilai total PD setiap 1 detik dimana nilai tersebut akan selalu diupdate setiap 1 detik. Flowchart diagram pada program dapat dilihat di Gambar 5. 


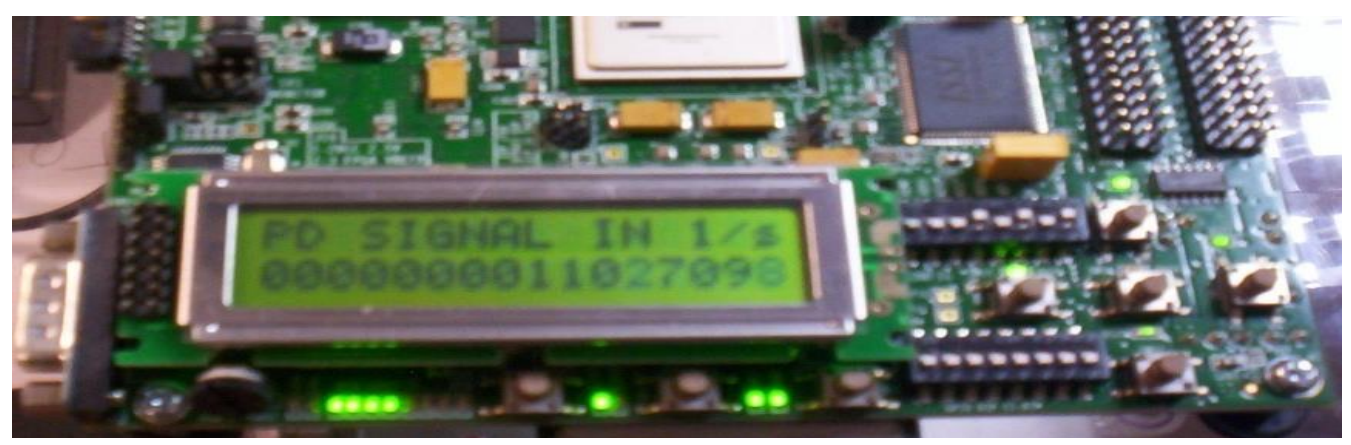

Gambar 4. LCD text 16x2 character Modul Pada Teknologi FPGA board

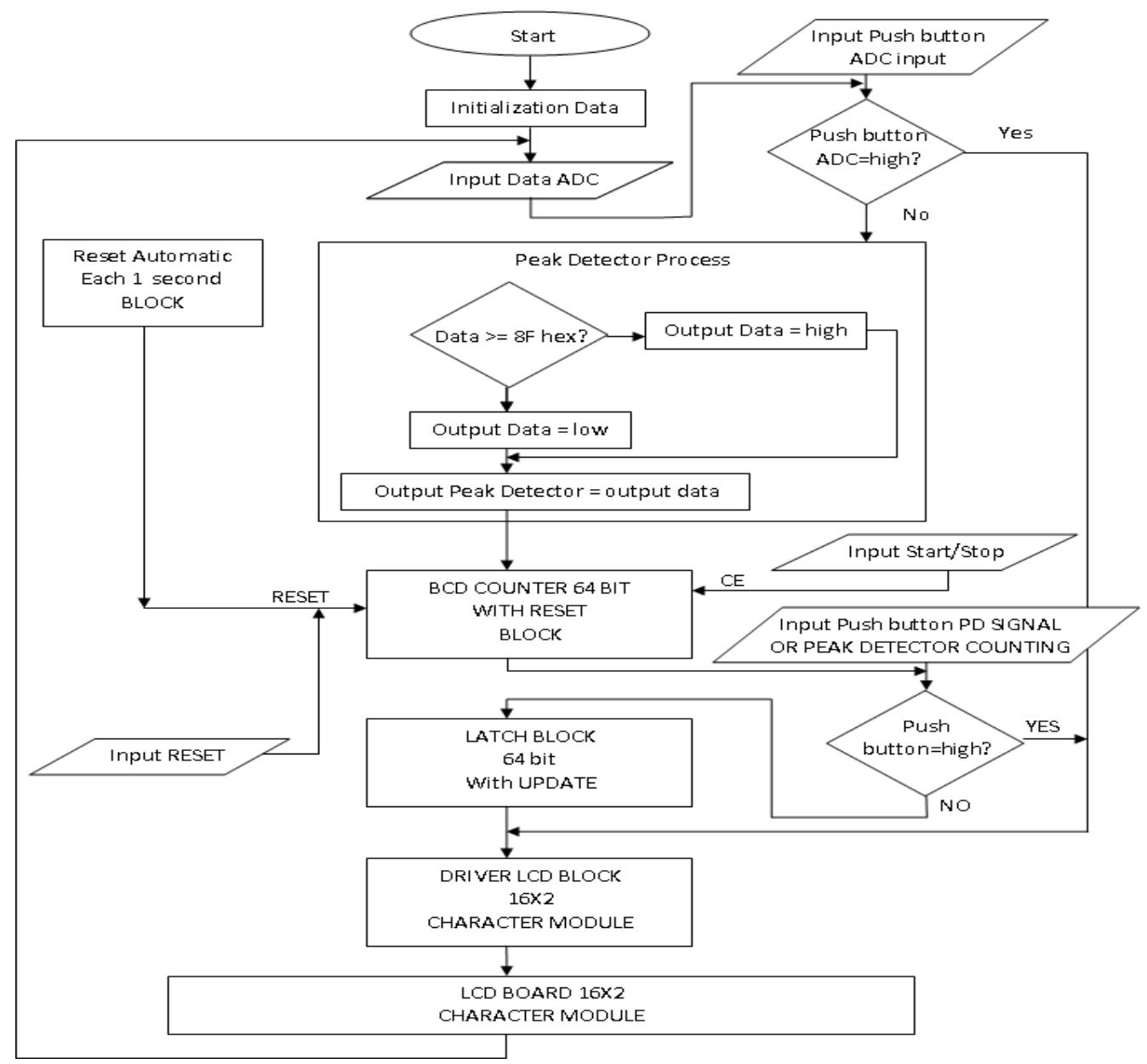

Gambar 5. Diagram Flowchart pada Sistem Rangkaian Deteksi Pulsa Lengkap

\section{Hasil dan Pembahasan}

\subsection{Hasil Test Uji Sistem Detektor PD Dengan Pico Pulse Generator}

Dalam pelaksanaan tes di laboratorium untuk rangkaian deteksi, ditunjukkan bahwa ia dapat mendeteksi jumlah impuls dengan cukup akurat. Ini ditunjukkan pada 
Gambar 1 di mana LCD membaca 84.746 impuls per detik ketika ditetapkan pada $84.746 \mathrm{KHz}$ berulang menggunakan generator impuls.

Kalibrasi sistem dilakukan dengan menggunakan tiga parameter yaitu amplitudo pulsa (V), frekuensi repetisi (f) dan lebar ( $\tau$ ). Tabel 1, 2 dan 3 menunjukkan hasil grafik count vs amplitudo (nilai $\mathrm{f}$ dan $\tau$ tetap), count vs frekuensi repetisi (nilai V dan $\tau$ tetap) dan count vs lebar pulsa (masing-masing nilai $\mathrm{f}$ dan $\mathrm{V}$ tetap). Semua tabel menunjukkan bahwa ada tingkat deteksi threshold yang tergantung pada amplitudo pulsa atau frekuensi repetisi atau lebar pulsa.

Tabel 1. Hasil Test dari Counts vs Amplitude (Nilai f dan $\tau$ tetap)

\begin{tabular}{ccccccc}
\hline No. & $\begin{array}{c}\text { Voltage } \\
\text { Analog } \\
\text { Signal }\end{array}$ & $\begin{array}{c}\text { Duration / } \\
\text { Pulse Width }\end{array}$ & $\begin{array}{c}\text { Frequency } \\
\text { Repetition }\end{array}$ & Period & $\begin{array}{c}\text { Result } \\
\text { PD signal/s } \\
\text { After } \\
\text { Calibration }\end{array}$ & $\begin{array}{c}\text { Result } \\
\text { PD signal/s } \\
\text { Before } \\
\text { Calibration }\end{array}$ \\
\hline 1 & $4,5 \mathrm{mVolt}$ & $50 \mathrm{~ns}$ & $10 \mathrm{KHz}$ & $100 \mathrm{us}$ & 0 & 0 \\
2 & $500 \mathrm{mVolt}$ & $50 \mathrm{~ns}$ & $10 \mathrm{KHz}$ & $100 \mathrm{us}$ & 0 & 0 \\
3 & $998 \mathrm{mVolt}$ & $50 \mathrm{~ns}$ & $10 \mathrm{KHz}$ & $100 \mathrm{us}$ & 0 & 0 \\
4 & $1,6 \mathrm{Volt}$ & $50 \mathrm{~ns}$ & $10 \mathrm{KHz}$ & $100 \mathrm{us}$ & 0 & 0 \\
5 & $2 \mathrm{Volt}$ & $50 \mathrm{~ns}$ & $10 \mathrm{KHz}$ & $100 \mathrm{us}$ & 0 & 0 \\
6 & $2,5 \mathrm{Volt}$ & $50 \mathrm{~ns}$ & $10 \mathrm{KHz}$ & $100 \mathrm{us}$ & 0 & 0 \\
7 & $3,2 \mathrm{Volt}$ & $50 \mathrm{~ns}$ & $10 \mathrm{KHz}$ & $100 \mathrm{us}$ & 0 & 0 \\
8 & $3,5 \mathrm{Volt}$ & $50 \mathrm{~ns}$ & $10 \mathrm{KHz}$ & $100 \mathrm{us}$ & 0 & 0 \\
9 & 4 Volt & $50 \mathrm{~ns}$ & $10 \mathrm{KHz}$ & $100 \mathrm{us}$ & 0 & 0 \\
10 & 4,5 Volt & $50 \mathrm{~ns}$ & $10 \mathrm{KHz}$ & $100 \mathrm{us}$ & 10000 & 11744 \\
11 & 5 Volt & $50 \mathrm{~ns}$ & $10 \mathrm{KHz}$ & $100 \mathrm{us}$ & 10000 & 11744 \\
\hline
\end{tabular}

\subsection{Analisis dan Pembahasan}

Hasil penelitian menunjukkan bahwa detektor puncak output dapat mendeteksi sinyal puncak dari sinyal input ADC ketika amplitudo sinyal PD lebih dari 4 Volt menggunakan ADC PIC Microcontroller 16F877A. Hasilnya menunjukkan sinyal PD adalah 11744 sinyal dalam 1s sebelum kalibrasi ketika frekuensi berulang 10 $\mathrm{kHz}$ dalam 1s. Setelah kalibrasi, hasilnya menunjukkan sinyal PD adalah 10000 sinyal dalam 1s sebelum kalibrasi ketika frekuensi berulang $10 \mathrm{kHz}$ dalam $1 \mathrm{~s}$.

Tabel 2. Hasil Tes dari Counts vs Repetitive frequency (Nilai V dan $\tau$ tetap After Calibration

\begin{tabular}{cccccc}
\hline No. & Period & $\begin{array}{c}\text { Frquency } \\
\text { Repetition }\end{array}$ & $\begin{array}{c}\text { Duration } \\
\text { Pulse Width }\end{array}$ & $\begin{array}{c}\text { Voltage } \\
\text { Analog Signal }\end{array}$ & $\begin{array}{c}\text { Result } \\
\text { PD Signal/s }\end{array}$ \\
\hline 1 & $10 \mathrm{us}$ & $100 \mathrm{KHz}$ & $50 \mathrm{~ns}$ & 5 Volt & 100000 \\
2 & $15 \mathrm{us}$ & $66.667 \mathrm{KHz}$ & $50 \mathrm{~ns}$ & 5 Volt & 66667 \\
3 & $20 \mathrm{us}$ & $50 \mathrm{KHz}$ & $50 \mathrm{~ns}$ & 5 Volt & 50000 \\
4 & $30 \mathrm{us}$ & $33.333 \mathrm{KHz}$ & $50 \mathrm{~ns}$ & 5 Volt & 33333 \\
5 & $40 \mathrm{us}$ & $25 \mathrm{Khz}$ & $50 \mathrm{~ns}$ & 5 Volt & 25000 \\
6 & $50 \mathrm{us}$ & $20 \mathrm{KHz}$ & $50 \mathrm{~ns}$ & 5 Volt & 20000 \\
7 & $60 \mathrm{us}$ & $16.667 \mathrm{KHz}$ & $50 \mathrm{~ns}$ & 5 Volt & 16667 \\
8 & $70 \mathrm{us}$ & $14.286 \mathrm{KHz}$ & $50 \mathrm{~ns}$ & 5 Volt & 14286 \\
9 & $80 \mathrm{us}$ & $12.500 \mathrm{KHz}$ & $50 \mathrm{~ns}$ & 5 Volt & 12500 \\
10 & $90 \mathrm{us}$ & $11.111 \mathrm{KHz}$ & $50 \mathrm{~ns}$ & 5 Volt & 11111 \\
11 & $100 \mathrm{us}$ & $10 \mathrm{KHz}$ & $50 \mathrm{~ns}$ & 5 Volt & 10000 \\
& & & & & \\
\hline
\end{tabular}


Tabel 3. Hasil Test dari Counts vs Pulse width (Nilai f dan V tetap) After Calibration

\begin{tabular}{cccccc}
\hline No. & $\begin{array}{c}\text { Duration } \\
\text { / Pulse Width }\end{array}$ & $\begin{array}{c}\text { Voltage } \\
\text { Analog Signal }\end{array}$ & $\begin{array}{c}\text { Frequency } \\
\text { Repetition }\end{array}$ & Period & $\begin{array}{c}\text { Result } \\
\text { PD Signal/s }\end{array}$ \\
\hline 1 & $1 \mathrm{~ns}$ & 5 Volt & $100 \mathrm{KHz}$ & $10 \mathrm{us}$ & 0 \\
2 & $10 \mathrm{~ns}$ & 5 Volt & $100 \mathrm{KHz}$ & $10 \mathrm{us}$ & 87148 \\
3 & $20 \mathrm{~ns}$ & 5 Volt & $100 \mathrm{KHz}$ & $10 \mathrm{us}$ & 100389 \\
4 & $30 \mathrm{~ns}$ & 5 Volt & $100 \mathrm{KHz}$ & $10 \mathrm{us}$ & 100389 \\
5 & $40 \mathrm{~ns}$ & 5 Volt & $100 \mathrm{KHz}$ & $10 \mathrm{us}$ & 100000 \\
6 & $50 \mathrm{~ns}$ & 5 Volt & $100 \mathrm{KHz}$ & $10 \mathrm{us}$ & 100000 \\
7 & $60 \mathrm{~ns}$ & 5 Volt & $100 \mathrm{KHz}$ & $10 \mathrm{us}$ & 100000 \\
8 & $70 \mathrm{~ns}$ & 5 Volt & $100 \mathrm{KHz}$ & $10 \mathrm{us}$ & 100000 \\
9 & $80 \mathrm{~ns}$ & 5 Volt & $100 \mathrm{KHz}$ & $10 \mathrm{us}$ & 100000 \\
10 & $90 \mathrm{~ns}$ & 5 Volt & $100 \mathrm{KHz}$ & $10 \mathrm{us}$ & 100000 \\
11 & $100 \mathrm{~ns}$ & 5 Volt & $100 \mathrm{KHz}$ & $10 \mathrm{us}$ & 100000 \\
\hline
\end{tabular}

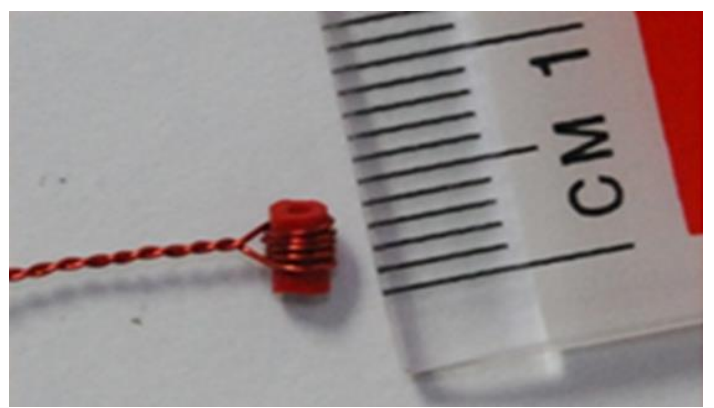

Gambar 5. Magnetic Probe Sensor

Sistem Tertanam Waktu nyata dari ADC Sistem Detektor PD dapat mendeteksi impuls sinyal PD secara akurat setelah kalibrasi. Tabel 1 menunjukkan hasil dari sinyal PD adalah 100000 sinyal dalam 1 detik setelah kalibrasi ketika frekuensi berulang $100 \mathrm{kHz}$ dalam 1 detik. Tabel 2 menunjukkan hasil Sistem detektor PD dapat mendeteksi sinyal PD secara akurat dari $10 \mathrm{kHz}$ hingga $100 \mathrm{kHz}$. Tabel 3 menunjukkan hasil Sistem detektor PD dapat mendeteksi sinyal PD secara akurat ketika lebar pulsa sinyal PD lebih dari 30 ns.

\section{Kesimpulan}

Simulasi tingkat laboratorium menggunakan ADC dari mikrokontroler berbiaya rendah dan Xilinx FPGA Virtex 4 untuk mendeteksi pulsa dari generator pulsa Pico telah berhasil ditunjukkan. Metode ini karenanya akan digunakan dalam pekerjaan masa depan tetapi menggunakan kecepatan pengambilan sampel gigahertz dengan input sinyal diferensial tegangan rendah (LVDS), bukan ADC sederhana dari mikrokontroler, dan FPGA untuk mendeteksi debit Partial Discharge (PD) dari kabel listrik bawah tanah menggunakan magnetic probe sensor seperti yang ditunjukkan pada Gambar 5.

Sistem deteksi PD dapat mendeteksi sinyal PD secara akurat. Ini ditunjukkan dalam sistem detektor PD di mana LCD membaca 84.746 impuls per detik ketika 
ditetapkan pada $84.746 \mathrm{KHz}$ berulang menggunakan Pico pulse generator. Hasilnya menunjukkan bahwa detektor puncak output dapat mendeteksi dengan benar sinyal puncak dari sinyal input ADC ketika lebar pulsa sinyal PD lebih dari 30 ns dan tegangan minimum 4,5 Volt menggunakan ADC dari PIC Microcontroller 16F877A. Keakuratan sistem deteksi PD dapat ditentukan sebagai berikut 1 PD masing-masing $30 \mathrm{~ns}(0,0333 \mathrm{GHz}$ atau 33,3 MHz $)=1 \mathrm{PD} / 33,3 \times 106 \mathrm{MHz}=3 \mathrm{x}$ 10-8 PD / Hz. Akurasi sistem sistem detektor PD adalah 3 x 10-8 PD / Hz.

\section{Ucapan Terima Kasih}

Saya ingin mengucapkan terima kasih kepada penyelia saya, Chandan Kumar Chakrabarty atas bimbingan, kesabaran, semangat dan semangat yang menyegarkan yang selalu menjadi sumber dorongan, komentar yang mendalam, dan bimbingan sepanjang pekerjaan penelitian ini. Tanpa motivasi, dukungan, dan dedikasinya, tesis ini tidak akan mungkin, tidak akan sejauh ini, dan tidak akan mencapai ketinggian ini. Terima kasih banyak.

Saya juga ingin menyampaikan rasa terima kasih saya yang terdalam kepada rekan pengawas saya, Ahmad Basri bin Abdul Ghani, Proyek Pemimpin TNBR, karena memberikan kesempatan untuk melakukan proyek penelitian ini dan menggunakannya sebagai proyek PhD saya. Saya ingin mengatakan, "Terima kasih banyak" kepada rekan penyelia saya, Agileswary K. Ramasamy atas bimbingan, kesabaran, dukungan dan dorongannya.

\section{Daftar Pustaka}

1. Partial Discharge Measurements, IEC Publication 270, 1981.

2. G.C. Stone, Partial discharge diagnostics and electrical equipment insulation condition assessment, IEEE Transactions on Dielectrics and Electrical Insulation.Volume: 12 , Issue: 5, 2005, pp. $891 \sim 904$.

3. S. Omwoma, M. Arowo, J. O. Lalah, K.W. Schramm, Environmental Impacts of Sugarcane Production, Processing and Management: A Chemists Perspective, Environmental Research Journal, Vol. 8, Issue 3 (2014), p. 195223.

4. Sharkawy, R.M.; Mangoubi, R.S.; Abdel-Galil, T.K.; Salama, M.M.A.; Bartnikas, R.; SVM classification of contaminating particles in liquid dielectrics using higher order statistics of electrical and acoustic PD measurements. 2007 IEEE Transactions on Dielectrics and Electrical Insulation. Volume: 14, 2007, pp. $669 \sim 678$.

5. Emilliano, Chandan Kumar Chakrabarty, Ahmad Basri, Agileswari K. Ramasamy, VHDL Simulation of Peak Detector, BCD Counter 64 Bit, Reset Automatic Block for PD Detection Circuit Using FPGA, International Conference 2010 6th International Colloquium on Signal Processing \& Its Applications UiTM and IEEE Control Systems Chapter, Malaysia Section, in Malacca, Malaysia, 21-23 May 2010.

6. Ahmad Basri bin Abdul Ghani, Detection of Partial Discharge in Underground Cable Using Magnetic Probe, in 2008 Doctoral Thesis in University Tenaga Nasional, Malaysia, 2008. 
7. F.H. Kreuger, Discharge Detection in High Voltage Equipment, A Heywood Book, Temple Press Books Ltd, London 1964

8. W. L. Weeks and Y. M. Diao, Wave Propagation Characteristics in Underground Power Cable, IEEE Transaction on Power Apparatus and System, Vol. PAS-103, No. 10, October 1984, page 2816 - 2826.

9. G.C. Stone, and S.A. Boggs, Propagation of Partial Discharge Pulses in Shielded Power Cable, Proceedings of Conference on Electrical Insulation \& Dielectric Phenomena, IEEE Publication 82CH1773-1, p.275, Oct 1982.

10. R. Jobava, D. Pommerenke, R. Heinrich, W. Kalkner and A Gheonjian, Calculation of Pulse Propagation in Coaxial Cables with Multi-Layered Insulation System, DIPED - 2000 Proceedings, page 35-40

11. D. Pommerenke and S. Sakaguchi, Application of Maxwell Solvers to PD Propagation - Part 1: Concept and Codes, DEIS Feature Article, IEEE Electrical Insulation Magazine, September/October 2002 - Vol.18, No.5. 